\title{
AVIATION MANAGEMENT JOB PLACEMENT: THE 2002 PERSPECTIVE
}

\section{Triant G. Flouris and Brian Gibson}

Auburn University

\begin{abstract}
Successful job placement of aviation management graduates is highly beneficial to university aviation management programs as well as organizations that offer positions to aviation management graduates. A critical aspect of job placement involves understanding the preferences and perceptions of students and employers regarding jobs. This paper reports the results of a survey of undergraduate aviation management students from four universities regarding their preferences and perceptions vis-à-vis employment. Results provided include a demographic profile of the respondents, their organization/functional area preferences and their perspectives on selected job selection factors and issues.
\end{abstract}

\section{INTRODUCTION}

Successful job placement of college graduates in aviation management positions is very important to the university programs that provide aviation management education and organizations that provide aviation management job opportunities. University aviation management programs that have achieved a sustained, high rate of student job placement benefit in a number of ways:

- Support for program accreditation - For those programs that reside in a College of Business and are AACSB (American Assembly of Collegiate Schools of Business) accredited, AACSB accreditation of Business Administration programs requires that "a review of placement of graduates from each program in light of the program's stated objectives," be performed as a part of curriculum evaluation. In addition, section S.2 of the AACSB Standards for Business Accreditation states that "students should receive assistance in making career decisions and in seeking employment to follow completion of their degree programs." The CAA (Council on Aviation Accreditation) states similar goals in its accreditation manual.
- Generation of student interest sustained placement of prospective graduates in organizations or jobs that are perceived by students as highly desirable attracts prospective students to the major and as a result, leads to program stability and growth.

- Improvement of external relations facilitating the right fit between student and employer leads to satisfied alumni and employers that can have a significant positive effect on future program support.

Organizations also benefit significantly from successful job placement efforts. Effective recruitment and selection of well-trained and educated aviation management candidates can have a positive impact on organizational performance. In addition, effective candidate selection may result in increased management retention rates and, as a result, lower replacement costs.

A critical aspect of successful aviation management job placement involves understanding both employer and student preferences and perceptions. Specifically, a better understanding of employer job requirements and competencies, candidate selection criteria and compensation practices as well as student job preferences, firm/job selection criteria and compensation plus workload perceptions facilitate job placement efforts. 
The purpose of this paper is to report the results of a survey involving undergraduate aviation management students from four major United States universities. A continuation of the study is also underway that involves results from aviation management employers. The surveys focus on group preferences and perceptions regarding job placement issues. Results provided in this paper include a demographic profile of the respondents, their organization/functional area preferences and their perspectives on selected job selection factors and issues. Hopefully, these research results will provide aviation management students, educators, and employers with information that can be used to improve aviation management student job placement.

\section{BACKGROUND}

Several research efforts have been undertaken to shed light on employer job requirements, competency preferences and employment practices. These studies have primarily addressed job requirements/skill competencies by functional area and employer recruitment, selection and compensation practices. While there is a growing body of literature concerning aviation management employer hiring requirements, preferences and perceptions, limited research has been conducted to determine aviation management student job preferences and perceptions. Also, little effort has been made to compare the two groups.

Past research in other fields indicates that these additional areas should be studied to gain a more complete perspective of the placement landscape and to facilitate placement processes. These previous studies found that (1) the student viewpoint is different from that of employers and faculty, and (2) employers and faculty are poor predictors of student preferences. Relevant individual findings include:

- Posner (1981) found significant differences in recruiter, student and faculty perceptions regarding important applicant and job characteristics. In addition, the study concluded that: "faculty are dismal judges of what students want from a job!"
- Gaedeke and Tootelian (1989) and Kelley and Gaedeke (1990) determined that marketing students and employers differed in the evaluation of desirable job attributes for entry-level sales and marketing jobs.

- Kirsch, Leathers and Snead (1993) found that the perceptions of accounting students and recruiters differed significantly regarding competencies considered important for performing an entry-level auditing position.

- Tackett, Wolf and Law (2001) determined that accounting internship employers and students have significant differences in perspective regarding ethical behavior and judgment of the interns' technical and communication skill level.

Collectively, these studies indicate that studying the student perspective and comparing the key group perceptions is important. Similar research in the aviation management discipline would be of value to employers and faculty.

\section{METHODOLOGY}

The research methodology consisted of several steps. These steps included: a literature review of research studies related to job placement preferences and perceptions (described in the preceding section), survey instrument design and testing, and data collection and analysis.

A variety of employment skills studies and the placement research described above were used to identify key issues, questions, and response options for this study. It was determined that student preferences regarding job selection factors, compensation, geographic preferences, and workload levels would be addressed. Also, student perceptions regarding candidate screening and selection criteria would be studied.

\section{Student Survey}

A four-page student questionnaire was developed to collect data (see Appendix). The survey instrument was pre-tested by 45 aviation management undergraduate students and revised 
to improve clarity and ease of completion. The potential study participants were identified as U.S. undergraduate students who will graduate in 2002 (April through December) and are seeking aviation management positions. Faculty members were asked to administer the student questionnaire to senior-level aviation management classes in which the target population could be easily reached.

The completed surveys were coded, entered into a PC, and analyzed using Microsoft Access 2000 and SPSS Release 10.0 for Windows. Responses containing nominal and ordinal data were analyzed using frequency counts, percentages, and cross-tabulations. Responses containing ratio data were analyzed using means, standard deviations, and Independent Samples t-tests. All statistical tests were conducted at a 95 percent confidence interval ( $p$-value $<.05)$.

\section{RESEARCH FINDINGS}

Survey results are grouped into two categories: demographics and student preferences, and student perceptions of employer preferences. The second category cannot be properly analyzed and compared until the results from the employer surveys have been collected and analyzed.

\section{Respondent Demographics}

A wide variety of students completed the questionnaire. The participants range in age from 21 to 42 years (mean age $=23.9$ years). Additional demographic information regarding the student respondents is presented in Table 1.

TABLE 1. STUDENT SURVEY PARTICIPANT DEMOGRAPHICS

\begin{tabular}{lcc}
\hline & $\begin{array}{c}\text { Frequency } \\
(\mathbf{n}=)\end{array}$ & Percentage \\
\hline Gender & 48 & 81.4 \\
$\quad$ Male & 11 & 18.6 \\
Female & & \\
& & \\
Marital Status & 46 & 78.0 \\
$\quad$ Not married & 10 & 16.9 \\
Married & 3 & 5.1 \\
$\quad$ Not disclosed & & \\
& & 89.47 \\
Graduation Date & 51 & 8.77 \\
$\quad$ May, 2002 & 5 & 0.00 \\
August, 2002 & 0 & 1.76 \\
December, 2002 & 1 & \\
2002, semester not indicated &
\end{tabular}

\section{Aviation Management Student Preferences}

Students were asked a series of questions regarding their job search activities. General information was sought regarding organization and position preferences, as well as interview activities. Specific issues regarding job selection factors, benefits and compensation, geographic location, and workload levels were also studied.

\section{General Information}

In an effort to understand preferences and potential competition for job openings, students were asked to identify the top three types of organizations they prefer to join and the top three types of positions that they are interested in. Most frequently cited organization types included major airlines, regional airlines, fixed based operators (FBO's), corporate 
aviation, and government agencies. It appears that today's students are interested in operational activities more so than staff-oriented responsibilities as revealed by the position type rankings. The most desired position type was flight crew, followed by flight operations, flight instruction and corporate aviation management. Information regarding other company and position types can be found in the completed student questionnaire in the Appendix.

Interview activity and success among the respondents is quite limited. Figure 1 reveals that nearly half of the Spring 2002 graduates have yet to participate in on campus interviews and an even greater percentage have not been invited for company site visits. Only ten percent of this group has accepted job offers, while nearly three-quarters have not been offered positions at the time of the survey. While the state of the economy may contribute to the low numbers of second interviews and offers, it appears that nearly half of the students have failed to mount a serious job search campaign, despite having fewer than four months until graduation!

\section{FIGURE 1. INTERVIEW ACTIVITY LEVELS}

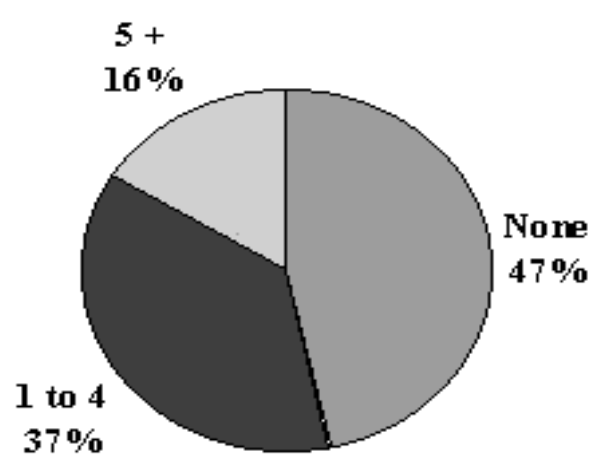

Campus Interviews for Spring 2002 Graduates

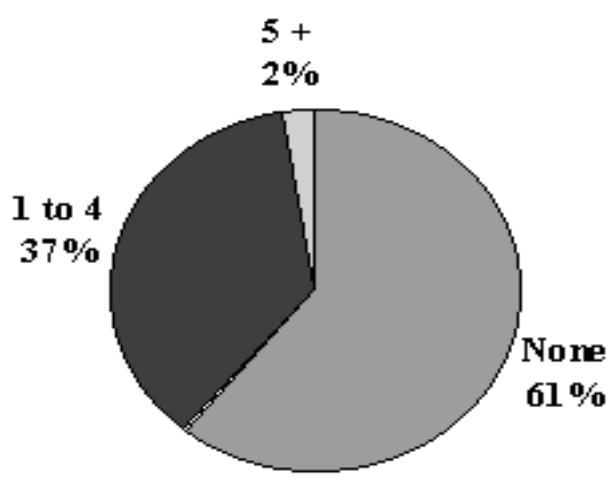

Company Interviews for Spring 2002 Graduates

\section{Job Selection Factors}

Regardless of their search and interview activity levels, the student respondents have a strong vision of what they desire in a position. Most importantly, they are looking for growth opportunities, fulfillment, stability, and a good environment with a satisfactory salary. Overall, the respondents rated 16 of the 19 job selection criteria high (5.0 or greater on a 7-point Likert scale where $1=$ low importance to $7=$ high importance). Surprisingly, the lowest rated item "frequent performance evaluations" is a key element in the respondents' highest rated criteria "opportunity for advancement."

\section{TABLE 2. JOB SEARCH AND SELECTION CRITERIA}

\begin{tabular}{lcc}
\hline \multicolumn{1}{c}{ Criteria } & Student Mean Rating $^{\mathbf{A}}$ & \begin{tabular}{c} 
Student $_{\text {Rankings }^{\mathbf{B}}}$ \\
\hline Opportunity for advancement
\end{tabular} \\
Anticipated job satisfaction & 6.47 & 1 \\
Job security & $6.12^{*}$ & 3 \\
Positive company atmosphere & $6.07^{*}$ & 4 \\
Salary offered & $6.06^{*}$ & 2 \\
Training provided & 6.04 & \\
\hline
\end{tabular}




\begin{tabular}{lc}
\hline Challenging and interesting work & 5.82 \\
Benefits package offered & $5.70^{*}$ \\
Personal fit with corporate culture & $5.62^{*}$ \\
Performance based bonuses & $5.56^{*}$ \\
Key job responsibilities & 5.52 \\
Geographic location of job & 5.31 \\
Company reputation and image & 5.28 \\
Limited nights and weekend hours & 5.22 \\
Opportunity to travel & 5.09 \\
Job autonomy & 5.01 \\
Signing bonus & $4.96^{*}$ \\
Flexible work schedule & $4.92^{*}$ \\
Frequent performance evaluations & 4.42 \\
\hline
\end{tabular}

${ }^{\text {A }}$ Based on 7 point scale: 1 = Low Importance to 7 = High Importance

B Based on weighted rankings of "the five factors that are most important to the job selection process"

* Significantly higher group mean at $\mathrm{p}<.05$

The group was also asked to rank order the top five factors in the job selection process. Table 2 identifies many similarities between each group's five most important criteria. The opportunity for advancement remains a critical issue, while salary offers jumped above other issues that had higher group means.

\section{Compensation and Benefits}

A critical aspect of the job evaluation and selection process is the compensation package offered. Student respondents were asked to provide information regarding anticipated salary offers and the importance of various benefits. Students were significantly more optimistic about the upper end of the salary scale than actual salaries $(\mathrm{p}=.018)$. While their desired compensation levels are higher than what they are willing to settle for, students appear to have a fairly realistic perception of what the market will bear in these relatively lean economic times.

Students also pay close attention to the other key component of compensation benefits. As a group, they rated eleven of 13 benefits as important in their job selection and evaluation process. Table 3 reveals that relatively long-range insurance and investment issues topped the list.

TABLE 3. IMPORTANCE OF BENEFITS

\begin{tabular}{lc}
\hline \multicolumn{1}{c}{ Criteria } & $\begin{array}{c}\text { Student Mean } \\
\text { Rating }\end{array}$ \\
\hline Medical insurance & $6.34^{*}$ \\
Retirement plan (401k, pension) & $6.17^{*}$ \\
Vacation and personal days & $6.12^{*}$ \\
Dental insurance & $5.91^{*}$ \\
Life insurance & $5.74^{*}$ \\
Stock options / purchase plans & $5.58^{*}$ \\
Paid sick leave & $5.41^{*}$ \\
Relocation expense support & 5.36 \\
Training and certification support & 5.25 \\
Profit sharing program & 5.11 \\
Tuition support / reimbursement & 5.05 \\
\hline
\end{tabular}




\begin{tabular}{ccc}
\hline Tailored benefits (cafeteria plan) & 4.01 \\
Company car / car allowance & $3.71 *$ \\
& * Based on 7 point scale: 1 = Low Importance to $7=$ High Importance \\
* Significantly higher group mean at $\mathrm{p}<.05$ &
\end{tabular}

Geographic Location Preferences

Another key factor in the job selection process is the locality of the positions offered. Employers and faculty often lament the lack of flexibility on the part of job candidates. Thus, a series of geographic location questions were asked to gain a better understanding of the students' perspectives on this topic. Students are quite geographically flexible. Over 44 percent of the students will consider a broad array of locations (either the U.S. or U.S. and international locations) while less than 25 percent limit themselves to specific cities or states. Additionally, the majority of students that indicated a regional preference will consider positions in two or more of the six regions presented in the questionnaire.
The primary reason for the students' geographic preferences is consistent with their level of flexibility - they are willing to relocate for perceived opportunities. Also, they indicated a relatively strong desire to remain in close proximity to family but do not want to live at home. Hence, the cost of living factor is another important consideration. Other factors were not as critical to the students, as Table 6 indicates.

A related question focused on the students' interest in work-related travel. Again, students displayed a high level of flexibility as more than 87 percent indicated a willingness to travel as needed for their jobs. On average, they are willing to travel 9.3 days per month (standard deviation of 5.2 days).

TABLE 4. REASONS BEHIND GEOGRAPHIC PREFERENCES

\begin{tabular}{lcc}
\hline Criteria & $\begin{array}{c}\text { Student Mean } \\
\text { Rating }\end{array}$ & $\begin{array}{c}\text { Student } \\
\text { Rankings }\end{array}$ \\
\hline Job opportunities in area & 5.92 & 2 \\
Close proximity to family & 5.51 & 1 \\
Cost of living & 5.34 & 3 \\
Social and cultural opportunities & 4.88 & \\
Close proximity to friends & 4.63 & 5 \\
Desire to go somewhere new & 4.57 & 4 \\
Climate & 4.47 & \\
Educational opportunities in area & 4.32 & \\
Spouse / significant other & 4.11 & \\
preferences & 4.05 & \\
Familiarity with area & 3.24 & \\
Opportunity to live at home & \\
A Based on 7 point scale: 1 = Low Importance to 7 = High Importance \\
B Based on weighted rankings of "the five geographic preference factors that are most \\
important to you"
\end{tabular}




\section{$\underline{\text { Workload Levels }}$}

The final job selection question focused on the weekly work hour expectations of the students. Student respondents were asked to provide a range of hours and a maximum level that they were willing to work each week. The group means were significantly different in terms of the low range of hours per week (p. = .001) but not in terms of the high range of hours per week. Based on the data, it is clear that many students do not have a reasonable understanding of the workload levels they face in aviation management positions.

This finding is also supported by the students' input regarding the maximum number of hours they are willing to work each week. While the group mean (51.30 hours per week) falls well within the industry's weekly requirements, Figure 2 reveals a wide range of responses, where nearly 40 percent of the students are not willing to work more than 50 hours per week.

\section{Student Perceptions on Employer Preferences}

Two employer-focused issues are also addressed in the study vis-à-vis the questionnaire that will be sent to employers. Data will be collected regarding the importance of various factors: (1) criteria used to review candidates' credentials in the screening process: and, (2) criteria used in candidate evaluation and selection. In the student questionnaire, respondents were asked to predict how employers would rate each criterion. Screening Criteria and Factors

Table 5 provides additional information regarding the screening evaluation criteria as far as the students are concerned.

FIGURE 2. MAXIMUM ACCEPTABLE WORKLOAD

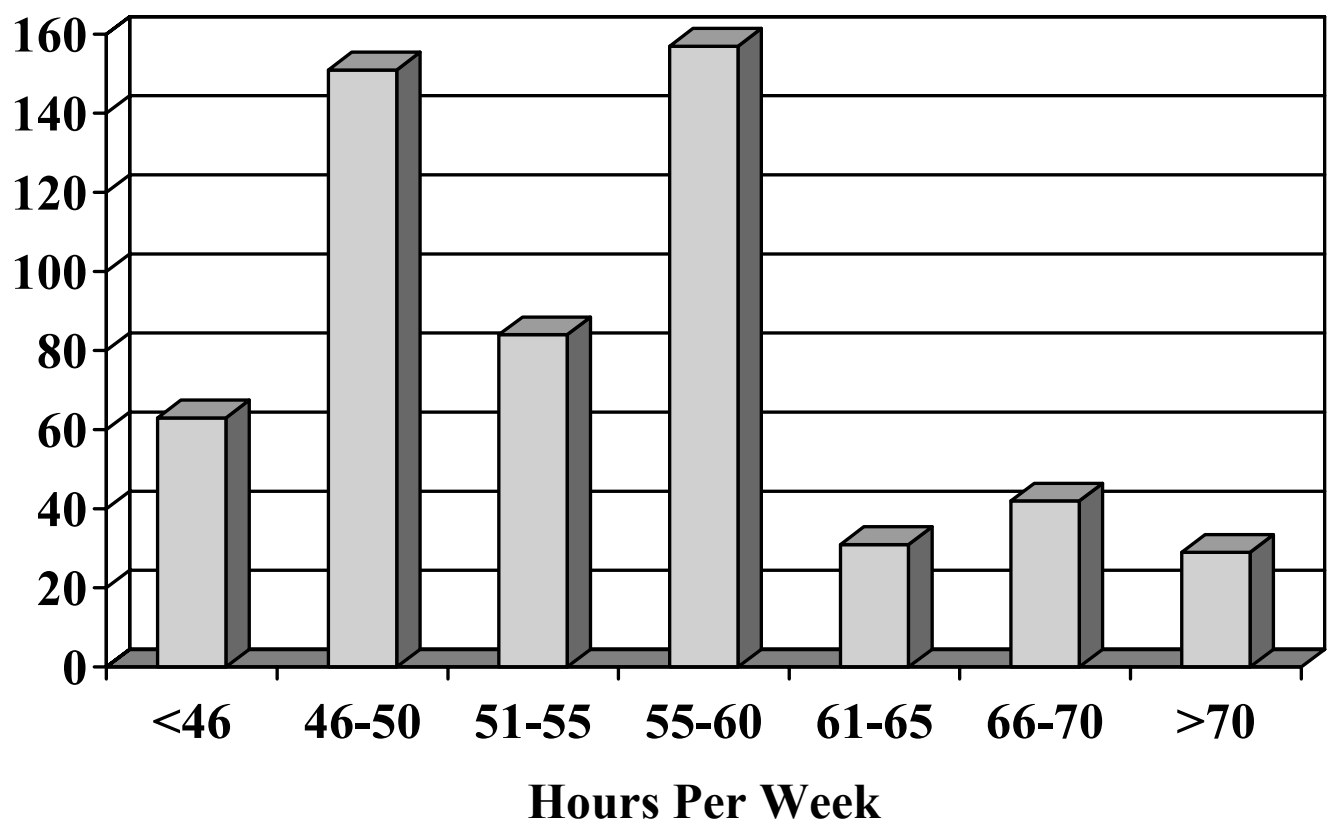


TABLE 5. CANDIDATE EVALUATION CRITERIA

\begin{tabular}{lcc}
\hline \multicolumn{1}{c}{ Criteria } & $\begin{array}{c}\text { Student Mean } \\
\text { Prediction }\end{array}$ & $\begin{array}{c}\text { Student } \\
\text { Rankings }\end{array}$ \\
\hline Communication skills & 6.15 & 1 \\
Leadership experience & $5.83^{*}$ & 4 \\
General work experience & $5.73^{*}$ & \\
Computer / technical skills & $5.54^{*}$ & 2 \\
Education - degree and major & $5.42^{*}$ & 5 \\
Quantitative skills & $5.33^{*}$ & 3 \\
Industry work experience & $5.18^{*}$ & \\
Internship / co-op experience & $5.00^{*}$ & \\
Classroom performance (GPA) & 4.86 & \\
Customer service experience & $5.20^{*}$ & \\
Date of availability & $4.80^{*}$ & \\
Extracurricular activities & $4.51^{*}$ & \\
Individual's stated objective & $4.78^{*}$ & \\
Professional organization activity & $4.77^{*}$ \\
Supervisory experience & $4.97^{*}$ & \\
Education - university attended & $5.09^{*}$ & \\
Reference list & $4.49^{*}$ & \\
\hline point scale: 1 = Low Importance to 7 = High Importance \\
eighted rankings of "the five factors that are most important to the job selection process" \\
y higher group mean at p<.05
\end{tabular}

The mean ratings of students' perceptions for 15 of the 17 criteria were high, while they did recognize the criticality of communication skills in the screening process. Table 5 indicates that students do not consider an emphasis on general work experience as very significant. Also, students tend to believe that employers focus more heavily on degree and major. Overall, the results suggest that students must avoid wasting resume space and screening interview time on issues that are relatively unimportant to employers. Of course, this point cannot be validated until we have the full results from the employer surveys.

\section{$\underline{\text { Selection Criteria and Factors }}$}

Students displayed a solid ability to place importance on the selection criteria that would be significant to employers. Table 6 highlights the mean importance ratings and rankings of the student group. 
TABLE 6. CANDIDATE SELECTION CRITERIA

\begin{tabular}{lcc}
\hline Criteria & $\begin{array}{c}\text { Student Mean } \\
\text { Prediction }\end{array}$ & $\begin{array}{c}\text { Student } \\
\text { Rankings }\end{array}$ \\
\hline Ability to prioritize, plan, \& & 6.31 & 2 \\
organize & 6.29 & 3 \\
Ability to work on teams & 6.27 & 5 \\
Oral communication skills & 6.13 & 1 \\
Ability to manage relationships & 6.21 & \\
Ability to learn quickly & 6.28 & \\
Ability to perform under pressure & 6.04 & \\
Motivation / enthusiasm & 6.11 & \\
Listening skills & $6.22^{*}$ & \\
Decision making skills & $6.17^{*}$ & \\
Problem solving skills & 5.76 & \\
Initiative / resourcefulness & $6.19^{*}$ & \\
Leadership skills & 5.87 & \\
Critical reasoning skills & 5.90 & \\
Self-confidence & 5.79 & \\
Ability to think creatively & $6.03^{*}$ & \\
Time management skills & 5.65 & \\
Assertiveness & $6.10^{*}$ & \\
Ability to see the "big picture" & $5.92^{*}$ & \\
Maturity & $5.78^{*}$ & \\
Goals / ambitions & $5.66^{*}$ & \\
Written communication skills & 5.11 & \\
Willingness to relocate & $5.83^{*}$ & \\
Industry knowledge / awareness & & \\
\hline
\end{tabular}

${ }^{A}$ Based on 7 point scale: 1 = Low Importance to 7 = High Importance

B Based on weighted rankings of "the five factors that are most important to the job selection process"

* Significantly higher group mean at $\mathrm{p}<.05$

Overall, the results revealed in the discussion, tables, and figures above reveal important insights into the placement preferences and perceptions of the key stakeholders. These insights and findings can be used to make the placement process more productive. Recruiters can use the enhanced knowledge of student desires and beliefs to develop more effective hiring practices. Finally, educators can use the comparative information, when it is available, and bridge the perceptual gaps between recruiters and students.

\section{IMPLICATIONS AND SUMMARY}

The "hot" job market in aviation management of just a year ago may still be lulling some potential entry-level aviation management candidates into thinking that companies will beat a path to their doorstep with lucrative offers. In reality, the market is much tighter today and students must take a more aggressive role in pursuing aviation management positions. Individuals seeking aviation management positions must take note of the important screening, evaluation, and selection criteria used by the employer respondents and their other requirements. Key recommendations and implications from the research include:

- Recognize that the economy has a tremendous impact on the types of positions available and adjust your 
search accordingly. Students may need to be more open to operations positions with aviation management service providers and general aviation instead of focusing on airlines and flight crew positions with airlines.

- Create a search plan and begin immediately. Nearly half of the Spring 2002 graduates have not had a single interview on campus or at the employer site. Higher unemployment rates are creating more competition for available positions and fewer companies are currently recruiting on campus. This squeeze from both ends means that the search process will generally require more effort and take a longer period of time. Waiting to start the process will only increase the likelihood of not being employed by graduation time.

- Moderate your compensation and workload expectations. Although the respondents had reasonable expectations for minimum acceptable salaries, their high end of the salary range was not in line with the industry. Also, a large proportion of the respondents do not appear to have a realistic understanding of the time commitment involved in this $24 / 7 / 365$ field. In today's marketplace students may need to settle for a bit less financially than they hope for and be ready to put in more hours than they would like to.

- Sell your unique capabilities, skills, and attributes. The employer respondents look for specific competencies and experiences that students must be able to communicate and demonstrate during interviews. Clearly, it's not about where you went to school or "who you know" (e.g., your references). In the minds of the employers, it's what you bring to the table in terms of leadership and work experience, interpersonal skills, technical aptitude, and geographic flexibility that sets you apart from the other candidates.

\section{Faculty Recommendations and Implications}

By nature of their responsibilities and desire to assist with student placement, faculty should have a vested interest in the results of the study. The following recommendations should assist faculty in this role:

- Faculty should encourage students to gain experience in numerous areas early in their career (e.g. flight operations, human resource management etc). The current classroom emphasis on flight operations integration promotes a student desire to have an entry-level job that involves integrating aviation management or corporate functions. However, it is likely that students will need functional experience before attempting integration.

- Faculty should encourage students to actively search for jobs earlier. They can facilitate the process by inviting employers to visit classes, conduct job fairs early in the semester, assign students to visit career services, turn in a resume for critiques, and make career issues a regular topic of discussion in the classroom.

- Faculty should add more internship/coop experiences to the curriculum so that students will have a more realistic view of upcoming career and workload responsibilities. They should also provide "real world" exposure to the aviation management field through site visits and tours, guest lectures from recent graduates, and frank discussion of the realities of the work world. Glossing over the challenges and problems in aviation management will only create unrealistic expectations for students.

- Faculty should encourage more interaction between prospective employers and students because this can narrow the perception gaps that have been identified in this research. Suggested methods for increasing interaction include student consulting projects, job shadowing, industry based 
cases with company involvement, and the other participative activities described above.

\section{Summary, Limitations, and Future Directions}

The development of effective job placement programs is important for university aviation management programs, their students, and companies that hire entry-level aviation management managers. An important, but not often addressed aspect of the search, evaluation, and selection process in aviation management is the student perspective. Until now, limited research has been conducted regarding student preferences, desires, and expectations.

This study provides insight into the views of 59 students (graduating seniors) from four major United States universities with aviation management programs and will be expanded to hopefully cover most universities in the United States that offer aviation management degrees. By the time that this study is done we hope to have data from approximately 100 universities and also, over 100 aviation corporations regarding aviation management job placement.

Organizations can use the study findings and recommendations to benchmark their placement processes and to assess their understanding of student views in order to enhance their potential for recruiting success. Students can also use the information to develop job search strategies and compensation expectations. Finally, faculty can use the results to identify key employment and career issues that warrant additional coverage in the classroom.

Appropriate methodological steps were taken to ensure that these results presented in the paper are reliable, valid, and unbiased. Even still, the authors make no pretense that the results are all-encompassing or present the definitive study on aviation management job placement preferences and perceptions. The information contained in the tables and figures are presented with the caution that only students from a few major aviation management programs participate in the study. However, the authors believe that the results can adequately depict the current issues in aviation management job placement.
The topic of aviation management job placement is important and deserves additional study. Perhaps the most valuable effort would be to conduct similar studies of aviation management students and employers in different countries to analyze variances in perspectives and preferences regarding job placement. Also, it would be beneficial to assess the views of graduate aviation management students and the employers who recruit them. Finally, it will be important to repeat this study periodically to assess the trends in student and employer preferences, as well as the impact of economic conditions on placement perspectives and practices. 


\section{APPENDIX \\ UNDERGRADUATE JOB PREFERENCES SURVEY}

\section{Job Preferences Survey}

This survey seeks to gather information about your plans for full-time employment upon graduation. Please follow the instructions carefully and provide us with your honest input. There are not "right" or "wrong" answers and all of your individual responses will be kept confidential. Thank you in advance for your input.

\section{BACKGROUND INFORMATION}

Please provide some basic demographic information:

Gender $\underline{M=48 ~ F=11} \quad$ Age $\underline{\text { Average 23.9 }} \quad$ Marital Status $\underline{\text { Married }=10 \text { Single }=\mathbf{4 6}}$

Residency (U.S. State) $\underline{11 \text { Different States }}$ Citizenship (country) $\underline{\text { USA }=\mathbf{5 8} \text { Not Disclosed }=\mathbf{1}}$

Please provide some basic information regarding your anticipated degree:

$\underline{57}$ Bachelors degree $\quad \underline{\mathbf{1}}$ MBA degree $\underline{\mathbf{1}}$ Other:

Major: 57 Aviation Related 1 Marketing 1 not disclosed Expected Graduation Date (Month/Year) 20

\section{INTERVIEW PLANS AND EXPERIENCE}

Please rank $\left(1=\right.$ top choice, $2=2^{\text {nd }}$ choice, etc $)$ the top THREE types of organizations that you prefer to work for:

3 Consulting firm

$\underline{13}$ Government agency

$\underline{1}$ Non-profit agency

$\underline{5}$ Aerospace manufacturer

$\underline{\mathbf{3 7}}$ Corporate aviation

Other:
47 Major airline

$\underline{37}$ Regional airline

$\underline{11}$ FBO (including Airport Management)

$\underline{5}$ Flight School

If you are seeking an aviation management position, please $\operatorname{rank}\left(1=\right.$ top choice, $2=2^{\text {nd }}$ choice, etc $)$ your top THREE areas of interest:

1 Customer service and support

0 Forecasting

$\underline{4}$ International operations

$\overline{\mathbf{1 4}}$ Flight Operations (management)

$\underline{\mathbf{2}}$ Ground Operations

16 Flight Crew

$7 \quad$ Aviation Safety / Security

$\underline{4}$ Sales / sales management / marketing Other: $\underline{2}$ Cabin Crew

0 Production Operations Management

$\underline{2}$ Air Traffic Control

$\underline{\mathbf{0}}$ Yield Management

$\underline{\mathbf{8}}$ Airport Management

11 Corporate Aviation Management

$\underline{12}$ Flight Instruction

$\underline{2}$

How many interviews have you participated in for full-time positions? (Check one per line)

On-campus / first interviews:

$\underline{46}$ None

$\underline{10}$ Between 1 and 4 
Company site / second interviews

44 None

10 Between 1 and 4

15 or more

Which statement best describes your current status?

$\mathbf{4 4}$ I have received no job offers to date

$\underline{\mathbf{5}}$ I have received $\underline{\mathbf{1 1}}$ offer(s), but have not accepted a position

$\underline{\mathbf{1 0}}$ I have received $\underline{\underline{2}}$ offer(s), and have accepted a position 


\section{JOB SELECTION FACTORS AND ISSUES}

Rate the following criteria as they apply to your job search and selection process (circle one number per criteria).

\begin{tabular}{llllllll}
\multicolumn{7}{c}{ Importance } \\
HOW & $\leftarrow$ & $\leftarrow \rightarrow$ & \\
HIGH & & & \\
1 & 2 & 3 & 4 & 5 & 6 & 7 & L. Opportunity for advancement \\
1 & 2 & 3 & 4 & 5 & 6 & 7 & M. Opportunity to travel \\
1 & 2 & 3 & 4 & 5 & 6 & 7 & N. Performance based bonuses \\
1 & 2 & 3 & 4 & 5 & 6 & 7 & O. Personal fit with corporate \\
1 & 2 & 3 & 4 & 5 & 6 & 7 & P. Positive company atmosphere \\
1 & 2 & 3 & 4 & 5 & 6 & 7 & Q. Salary offered \\
1 & 2 & 3 & 4 & 5 & 6 & 7 & R. Training provided \\
1 & 2 & 3 & 4 & 5 & 6 & 7 & S. Free/discounted Travel \\
1 & 2 & 3 & 4 & 5 & 6 & 7 & T. Other \\
1 & 2 & 3 & 4 & 5 & 6 & 7 & U. Addiction to Aviation \\
1 & 2 & 3 & 4 & 5 & 6 & 7 &
\end{tabular}

Importance
LOW $\leftarrow \leftarrow \rightarrow \rightarrow$
HIGH

$\begin{array}{lllllll}1 & 2 & 3 & 4 & 5 & 6 & 7\end{array}$

$\begin{array}{lllllll}1 & 2 & 3 & 4 & 5 & 6 & 7\end{array}$

$\begin{array}{llllllllll}1 & 2 & 3 & 4 & 5 & 6 & 7\end{array}$

$\begin{array}{lllllll}1 & 2 & 3 & 4 & 5 & 6 & 7\end{array}$

$\begin{array}{lllllll}1 & 2 & 3 & 4 & 5 & 6 & 7\end{array}$

$\begin{array}{llllllll}1 & 2 & 3 & 4 & 5 & 6 & 7\end{array}$

$\begin{array}{lllllll}1 & 2 & 3 & 4 & 5 & 6 & 7\end{array}$

$\begin{array}{lllllll}1 & 2 & 3 & 4 & 5 & 6 & 7\end{array}$

$\begin{array}{lllllll}1 & 2 & 3 & 4 & 5 & 6 & 7\end{array}$

$\begin{array}{lllllll}1 & 2 & 3 & 4 & 5 & 6 & 7\end{array}$
K. Advantageous rest schedule

I. Job security

J. Key job responsibilities

Using the letters listed next to each factor, identify the five that are most important to your job selection process (fill in the blanks - start at $1^{\text {st }}$ with the most important criteria to you):
$1^{\text {ST }}{ }^{\mathrm{A}}$
$2^{\mathrm{ND}}-\mathrm{C}$
$3^{\mathrm{RD}} \mathrm{L}$
$4^{\mathrm{TH}}-\mathrm{U}$
$5^{\mathrm{TH}}$

Rate the importance of the following benefits to your job evaluation and selection process (circle one number per benefit).

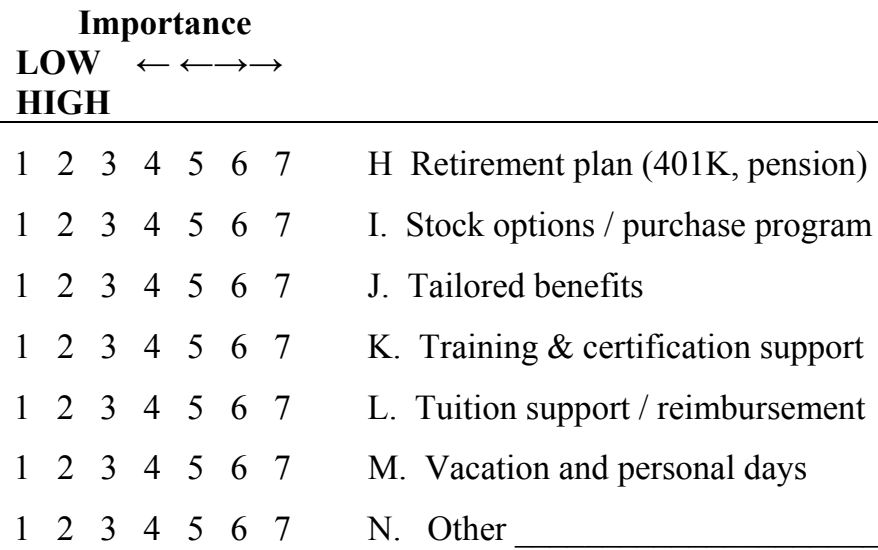
A. Company car / car allowance
B. Dental insurance
C. Life insurance
D. Medical insurance
E. Paid sick leave
F. Profit sharing program
G. Relocation expense support

$\begin{array}{lllllll}1 & 2 & 3 & 4 & 5 & 6 & 7\end{array}$

Importance
LOW $\leftarrow \leftarrow \rightarrow \rightarrow$
HIGH

$\begin{array}{lllllll}1 & 2 & 3 & 4 & 5 & 6 & 7\end{array}$

$\begin{array}{lllllll}1 & 2 & 3 & 4 & 5 & 6 & 7\end{array}$

$\begin{array}{lllllll}1 & 2 & 3 & 4 & 5 & 6 & 7\end{array}$

$\begin{array}{lllllll}1 & 2 & 3 & 4 & 5 & 6 & 7\end{array}$

$\begin{array}{lllllll}1 & 2 & 3 & 4 & 5 & 6 & 7\end{array}$

$\begin{array}{lllllll}1 & 2 & 3 & 4 & 5 & 6 & 7\end{array}$

$\begin{array}{lllllll}1 & 2 & 3 & 4 & 5 & 6 & 7\end{array}$

Using the letters listed next to each benefit, identify the five factors that are most important to your job selection process (fill in the blanks - start at $1^{\text {st }}$ with the most important benefit to you):

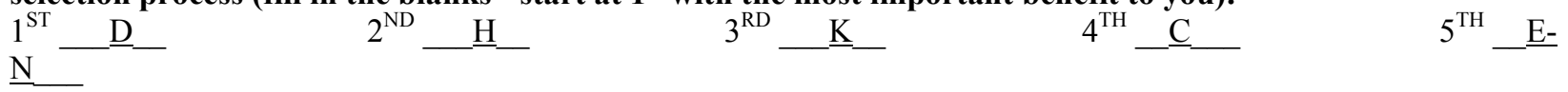


Please provide information on your anticipated starting salary (do not include bonuses):

Annual salary range expected $\$ \underline{\mathbf{4 0 , 2 4 0}}, 000$ to $\$ \_\mathbf{2 7 , 2 4 5} \_, 000 \quad$ Minimum acceptable annual salary $\$ \quad \mathbf{2 3 , 5 5 7}, 000$

Please provide information regarding the number of hours per week that you expect to work:

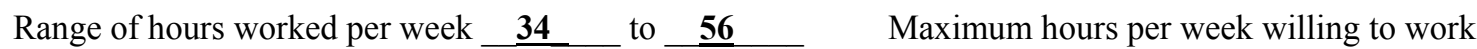
80 


\section{EMPLOYER PERSPECTIVES AND ISSUES}

Rate the following criteria in terms of their importance to employers as they review candidates' resumes for aviation positions (circle one number per criteria).

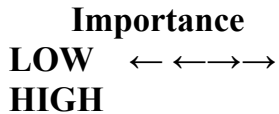

$\begin{array}{lllllll}1 & 2 & 3 & 4 & 5 & 6 & 7\end{array}$

$\begin{array}{lllllll}1 & 2 & 3 & 4 & 5 & 6 & 7\end{array}$

$\begin{array}{lllllll}1 & 2 & 3 & 4 & 5 & 6 & 7\end{array}$

$\begin{array}{llllllllll}1 & 2 & 3 & 4 & 5 & 6 & 7\end{array}$

$\begin{array}{llllllll}1 & 2 & 3 & 4 & 5 & 6 & 7\end{array}$

$\begin{array}{llllllll}1 & 2 & 3 & 4 & 5 & 6 & 7\end{array}$

$\begin{array}{lllllll}1 & 2 & 3 & 4 & 5 & 6 & 7\end{array}$

$\begin{array}{lllllll}1 & 2 & 3 & 4 & 5 & 6 & 7\end{array}$

$\begin{array}{lllllll}1 & 2 & 3 & 4 & 5 & 6 & 7\end{array}$
J. Individual's stated objective

$\mathrm{K}$. Industry work experience

L. Internship / coop experience

M. Leadership experience

N. Quantitative skills

O. Professional organization activity

P. Reference list

Q. Flight Experience (Total Time)

R. Other:
Importance

LOW $\leftarrow \longleftrightarrow \longrightarrow \rightarrow$ HIGH

$\begin{array}{lllllll}1 & 2 & 3 & 4 & 5 & 6 & 7\end{array}$

$\begin{array}{lllllll}1 & 2 & 3 & 4 & 5 & 6 & 7\end{array}$

$\begin{array}{lllllll}1 & 2 & 3 & 4 & 5 & 6 & 7\end{array}$

$\begin{array}{lllllll}1 & 2 & 3 & 4 & 5 & 6 & 7\end{array}$

$\begin{array}{lllllll}1 & 2 & 3 & 4 & 5 & 6 & 7\end{array}$

$\begin{array}{lllllll}1 & 2 & 3 & 4 & 5 & 6 & 7\end{array}$

$\begin{array}{lllllll}1 & 2 & 3 & 4 & 5 & 6 & 7\end{array}$

$\begin{array}{lllllll}1 & 2 & 3 & 4 & 5 & 6 & 7\end{array}$

$\begin{array}{lllllll}1 & 2 & 3 & 4 & 5 & 6 & 7\end{array}$

Using the letters listed next to each factor, identify the five that you believe are most important to employers in the resume review process (fill in the blanks - start at $1^{\text {st }}$ with the most important criteria):
$1^{\text {ST }}$ Q
$2^{\mathrm{ND}}-\underline{\mathrm{B}}$
$3^{\mathrm{RD}} \underline{\mathrm{F}}$
$4^{\mathrm{TH}} \underline{\mathrm{D}}$
$5^{\mathrm{TH}}$

A

Rate the following skills and factors in terms of their importance to employers as they interview and select new managers for aviation positions (circle one number per criteria).

\begin{tabular}{ll} 
Importance & \multicolumn{1}{|c}{ Importance } \\
LOW $\leftarrow \leftarrow \rightarrow \rightarrow$ & LOW $\leftarrow \leftarrow \rightarrow \rightarrow$ \\
HIGH & HIGH
\end{tabular}
A. Ability to learn quickly
$\begin{array}{lllllll}1 & 2 & 3 & 4 & 5 & 6 & 7\end{array}$
M. Initiative / resourcefulness
$\begin{array}{lllllll}1 & 2 & 3 & 4 & 5 & 6 & 7\end{array}$
B. Ability to manage relationships
$\begin{array}{lllllll}1 & 2 & 3 & 4 & 5 & 6 & 7\end{array}$
N. Leadership skills
$\begin{array}{lllllll}1 & 2 & 3 & 4 & 5 & 6 & 7\end{array}$
C. Ability to perform under pressure
$\begin{array}{lllllll}1 & 2 & 3 & 4 & 5 & 6 & 7\end{array}$
O. Listening skills
$\begin{array}{lllllll}1 & 2 & 3 & 4 & 5 & 6 & 7\end{array}$
D. Ability to prioritize, plan, \&
$\begin{array}{lllllll}1 & 2 & 3 & 4 & 5 & 6 & 7\end{array}$
P. Maturity
$\begin{array}{lllllll}1 & 2 & 3 & 4 & 5 & 6 & 7\end{array}$ organize
E. Ability to see the "big picture"
$\begin{array}{lllllll}1 & 2 & 3 & 4 & 5 & 6 & 7\end{array}$
Q. Motivation / enthusiasm
$\begin{array}{lllllll}1 & 2 & 3 & 4 & 5 & 6 & 7\end{array}$
F. Ability to think creatively
$\begin{array}{lllllll}1 & 2 & 3 & 4 & 5 & 6 & 7\end{array}$
R. Oral communication skills
$\begin{array}{lllllll}1 & 2 & 3 & 4 & 5 & 6 & 7\end{array}$
G. Ability to work on teams
$\begin{array}{lllllll}1 & 2 & 3 & 4 & 5 & 6 & 7\end{array}$
S. Problem solving skills
$\begin{array}{lllllll}1 & 2 & 3 & 4 & 5 & 6 & 7\end{array}$
H. Assertiveness
$\begin{array}{lllllll}1 & 2 & 3 & 4 & 5 & 6 & 7\end{array}$
T. Self-confidence
$\begin{array}{lllllll}1 & 2 & 3 & 4 & 5 & 6 & 7\end{array}$
I. Critical reasoning skills
$\begin{array}{lllllll}1 & 2 & 3 & 4 & 5 & 6 & 7\end{array}$
U. Time management skills
$\begin{array}{lllllll}1 & 2 & 3 & 4 & 5 & 6 & 7\end{array}$
J. Decision making skills
$\begin{array}{lllllll}1 & 2 & 3 & 4 & 5 & 6 & 7\end{array}$
$\mathrm{V}$. Willingness to relocate
$\begin{array}{lllllll}1 & 2 & 3 & 4 & 5 & 6 & 7\end{array}$
K. Goals / ambitions
$\begin{array}{lllllll}1 & 2 & 3 & 4 & 5 & 6 & 7\end{array}$
W. Written communication skills
$\begin{array}{lllllll}1 & 2 & 3 & 4 & 5 & 6 & 7\end{array}$
L. Industry knowledge / awareness
$\begin{array}{lllllll}1 & 2 & 3 & 4 & 5 & 6 & 7\end{array}$
X. Other
$\begin{array}{lllllll}1 & 2 & 3 & 4 & 5 & 6 & 7\end{array}$ 
Using the letters listed next to each factor, identify the five that you believe are most important to employers in the recruiting and selection process (fill in the blanks - start at $1^{\text {st }}$ with the most important criteria):

$1^{\text {ST }} \underline{\text { N }}$

$2^{\mathrm{ND}} \underline{\mathrm{A}}$

$3^{\mathrm{RD}} \underline{\mathrm{C}}$

$4^{\mathrm{TH}} \underline{\mathrm{J}}$

$5^{\mathrm{TH}}$ 


\section{GEOGRAPHIC LOCATION ISSUES}

Which statement best describes your geographic preference for a job? (Check one and identify targeted locations):

$\underline{\mathbf{3}}$ I will consider positions only in certain cities

City Names:

$\underline{\mathbf{3}}$ I will consider positions only in certain states

State names:

15 I will consider positions only in certain regions

Region numbers (from map at right)

$\underline{\mathbf{1 8}}$ I will consider positions anywhere in the U.S.A.

$\underline{17}$ I will consider positions inside or outside the U.S.A.

0 I will only consider positions outside the U.S.A.

Countries:

Rate the reasons for your geographic preference (circle one number per criteria):

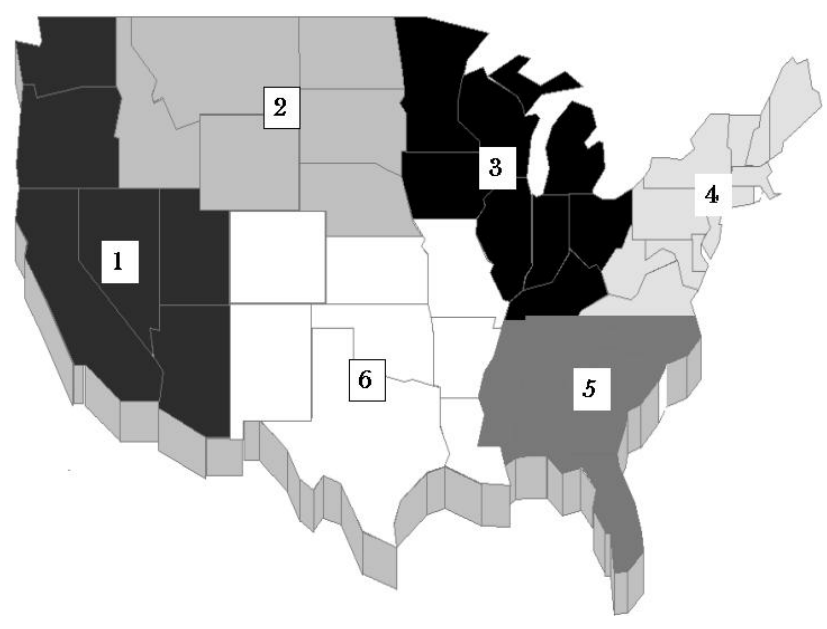

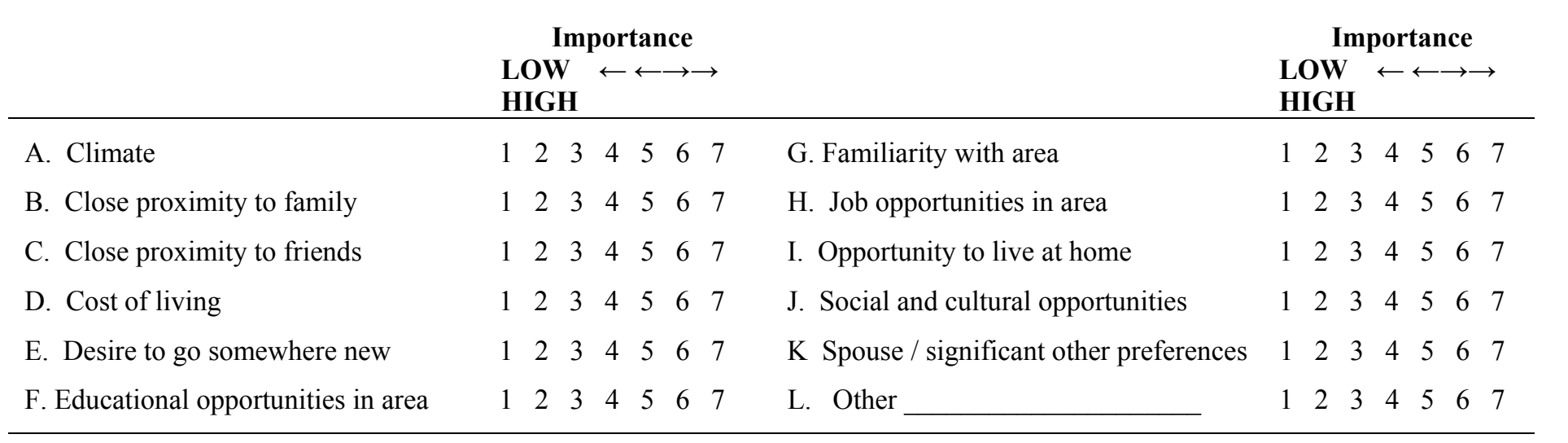

Using the letters listed next to each geographic preference factor, identify the five that are most important to you (fill in the blanks - start at $1^{\text {st }}$ with the most important factor):

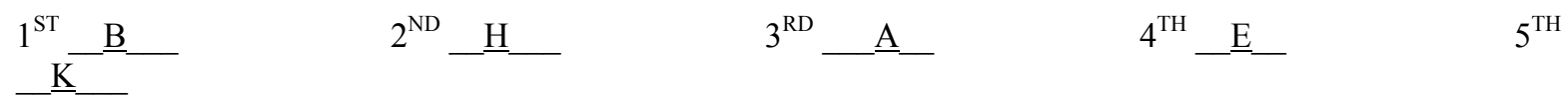

Thank you for your time and input. We will be conducting a similar survey with students and recruiters from around the country. We will share our results with your professor before the end of the semester. They will be able to provide you with some overall result. 


\section{REFERENCES}

AACSB, Standards For Business Accreditation. (1999). The International Association For Management Education, pg. 21. St. Louis, MO.

Plowman, E. G. (1971). Future Directions In Logistics Education, Logistics Education: Curriculum Design and Teaching Technology, Transportation Research Forum.

Gibson, B., Rutner, S. and Menachof, D. (1997). "Promoting Logistics Education: Encouraging A "Major" Decision," Removing the Barriers: The Transportation and Logisitcs Research Fund, Columbus, OH: The Ohio State University), pp. 199-224.

Russell, S. (1997). “The Coming of Age of Business Logistics, ”Journal of Marketing Education, 70.

Stutler, D. and Calvario, D. (1996). "In Alumni Support, Satisfaction Matters," Fund Raising Management, 27:9, pp. 12-13

Daugherty, P.J., Lusch, R.F., Myers, M. and Griffith, D. (2000). "Linking Compensation and Retention," Supply Chain Management Review, 4:3, pp. 64-72.

The Warehousing Research Center-Miami University. (1997). A Guide For Establishing Warehouse Job Descriptions, $2^{\text {nd }}$ Edition (Oak Brook, IL: WERC.

LeMay, S. and Carr, J. (1999). The Growth and Development of Logistics Personnel. Oak Brook, IL: Council of Logistics Management.

Management Association of Illinois. (2000). Warehousing Salaries and Wages. Oak Brook, IL: WERC.

Walsh, E. (2001). “You Can Take It With You,” Logistics Management \& Distribution Report, pp. 57-65.

Cook, R. and Gibson, B. (2000). "Management Development and Retention Programs in U.S. ThirdParty Aviation management Firms," Journal of Transportation Management, 12:1, pp. 1-18.

Ginter, J. and LaLonde, B. (2001). “The Ohio State University 2001 Survey of Career Patterns in Logistics," Annual Conference Proceedings (Oak Brook, IL: Council of Logistics Management.

Gibson, B. and Cook, R. (2001). "Hiring Practices in U.S. Third-Party Logistics Firms," International Journal of Physical Distribution \& Logistics Management, 31:10.

Phillips, C. and Phillips, A. (1998). "The Tables Turned: Factors MBA Students Use In Deciding Among Prospective Employers," Journal of Employment Counseling, 35:4, pp. 162-168.

Honeycutt, E., Ford, J., Swenson, M. and Swinyard, W. (1999) "Student Preferences For Sales Careers Around The Pacific Rim,” Industrial Marketing Management, 28:1 (1999), pp. 27-36.

Posner, B. (1981). "Comparing Recruiter, Student, and Faculty Perceptions of Important Applicant And Job Characteristics," Personnel Psychology, 34:2, pp. 329-339.

Gaedeke, R. and Tootelian, D. (1989). "Gap Found Between Employers' and Students' Perceptions of Most Desirable Job Attributes," Marketing News, 23, p. 42. 
Kelley, C. and Gaedeke, R. (1990). "Student And Employer Evaluation Of Hiring Criteria For EntryLevel Marketing Positions," Journal of Marketing Education, pp. 64-71.

Kirsch, R., Leathers, P. and Snead, K. (1993). "Student Versus Recruiter Perceptions Of The Importance Of Staff Auditor Performance Variables," Accounting Horizons, 7:4, pp. 58-69.

Tackett, J., Wolf, F. and Law, D. (2001). “Accounting Interns And Their Employers: Conflicting Perceptions,” Ohio CPA Journal, 60:2, pp. 54-56.

Bottoms, D., (1995). "Snubbed," Industry Week, 244:11, pp. 13-14. Wu Xianghan, "A Study on the Current Job-Selection Preferences of Postgraduate Students," Chinese Education and Society, $28: 5$, pp. 69-85.

Gammelgaard, B. and Larson, P.D. (2001). "Logistics Skills and Competencies for Supply Chain Management," Journal of Business Logistics, 22:2, pp. 27-50. 